\title{
Developing an Interactive Multimedia Application for Teaching Fard Salah to Children
}

\author{
Nizar Alam Hamdani ${ }^{1}$, Erwin Yulianto ${ }^{2}$ \\ \{nizar_hamdani@uniga.ac.id ${ }^{1}$,rwinyulianto@yahoo.com²\} \\ Universitas Garut ${ }^{1}$, Universitas Langlangbuana ${ }^{2}$
}

\begin{abstract}
Salah is one of the Five Pillars of Islam and an obligation for every Muslim. Therefore, it is necessary to provide children with lessons on salah at an early age. Using an incremental model, this study attempts to develop an interactive multimedia application for the purpose of teaching children how to perform salah. It is expected that the developed multimedia application can facilitate children's learning about salah in an effective and interesting way.
\end{abstract}

Keywords: Application Development, Instructional Media, Salah Lesson for Children.

\section{Introduction}

In the era of industry 4.0, digital applications have been used in almost every aspect of life [1], including education. Digital applications can even be used for the purpose of teaching children how to perform salah, which is the second Pillar of Islam. Salah is one of the most important ibadahs in Islam. In a hadith, it is said that salah is the pillar of religion; he who upholds salah has upheld the religion. Therefore, it is necessary for children to learn how to perform salah from an early age.

Salah tutorials are mostly documented in books [2]. Salah tutorial materials available on the Internet are even taken from books. Learning salah from books can be a burdensome for some children because they have to memorize salah recitations and adjust them to the movements in a simultaneous manner.

Table 1 summarizes some related studies.

Table 1. Related previous studies

\begin{tabular}{|c|c|c|}
\hline Author(s) & Methodology & Kesimpulan \\
\hline Zaitun and Habiba [3] & $\begin{array}{l}\text { Quantitative } \\
\text { survey }\end{array}$ & $\begin{array}{l}\text { Participants did not consistently offer five daily salahs } \\
\text { despite the fact that they knew that salah is an obligation } \\
\text { for them. }\end{array}$ \\
\hline $\begin{array}{l}\text { Trenawati and } \\
\text { Fadzilatunnisa }[4]\end{array}$ & $\begin{array}{l}\text { Descriptive } \\
\text { study }\end{array}$ & $\begin{array}{l}\text { Text- and audio-based instructional media improves } \\
\text { children's interests in learning salah and wudu. }\end{array}$ \\
\hline Jasri and Faid [5] & $\begin{array}{l}\text { Descriptive } \\
\text { study }\end{array}$ & $\begin{array}{l}\text { Flash-based media helps parents with teaching salah to } \\
\text { their children }\end{array}$ \\
\hline
\end{tabular}

The present study attempts to develop an audiovisual multimedia application to help children learn how to perform five daily prayers. The multimedia application is designed in a such a way that it enables an interactive learning environment to provide a basis for effective student-teacher oriented instruction. 


\section{Method}

\subsection{Descriptive Method}

The present study was conducted using a descriptive method. The purpose is to systematically collect information as much as possible of a factual phenomenon through a participant observation, which serves as the main data collection technique [6]. In addition, research data were also collected through interviews and documentary studies. The study was conducted using the following procedures:

1. Review of relevant literature including books and scientific articles.

2. Comparing software for interactive applications that can be used for the multimedia designing.

3. Internet browsing for relevant information

4. Holding a focus group discussion with parents, kindergarten and elementary school teachers about how to teach salah to children.

\subsection{Software Development Life Cycle}

In the present study, the application was developed using an incremental model, which is a combination of waterfall model elements that are applied repeatedly, or can be said a combination between sequential linear and prototype model [7]. The incremental model was chosen due to the small scale project and limited time [8]. The developmental process is illustrated in Figure 1.

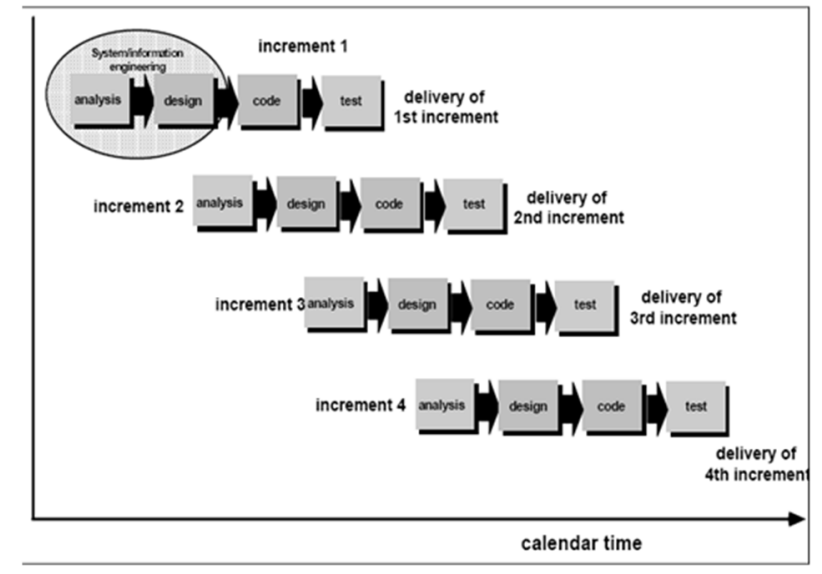

Figure. 1. Incremental Model [9]

The incremental model offers the following advantages:

1. It provides optimal working environment.

2. It can flexibly accommodate changes in a relatively short time with a small work team.

3. The consumer can immediately use the parts that have been completed prior to the completion of whole system

4. It can maximize the return on investment 
The incremental model also suits the purpose of this study because there are some functions that require adjustment between prayer recitations and movement.

\section{Result and Discussion}

\subsection{Business Process Analysis}

Learning how to perform salah from books and teacher's direct instructions may have the following limitations:

1. Monotonous instruction.

2. Children's lack of learning interests.

3. Children's limited concentration.

4. Lack of interactivity.

5. Lack of audio.

6. Potential of misinformation delivery by the teacher.

Based on the above analysis, the conventional learning system can be illustrated in a business process presented in Figure 2.

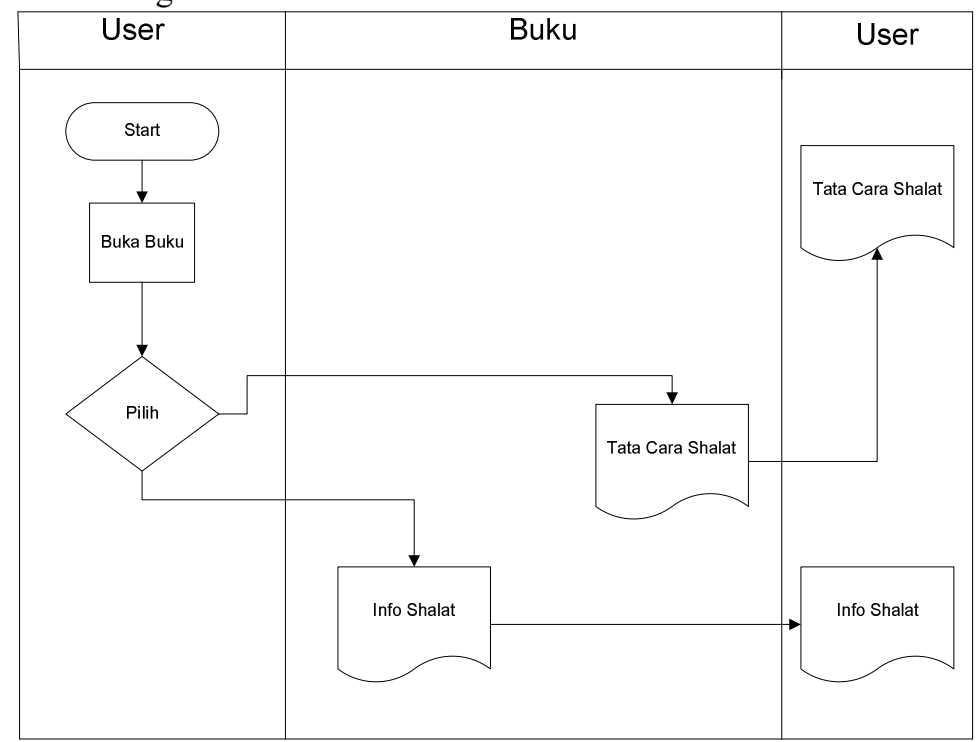

Figure. 2. Old Business Process

The new system design is expected to be able to patch these deficiencies and provide more advantages than the old business process in the form of interactive audiovisual delivery. Children can listen to prayer recitations in accordance with the salah movement they select on the application interface. The new business process can be illustrated in Figure 3. 


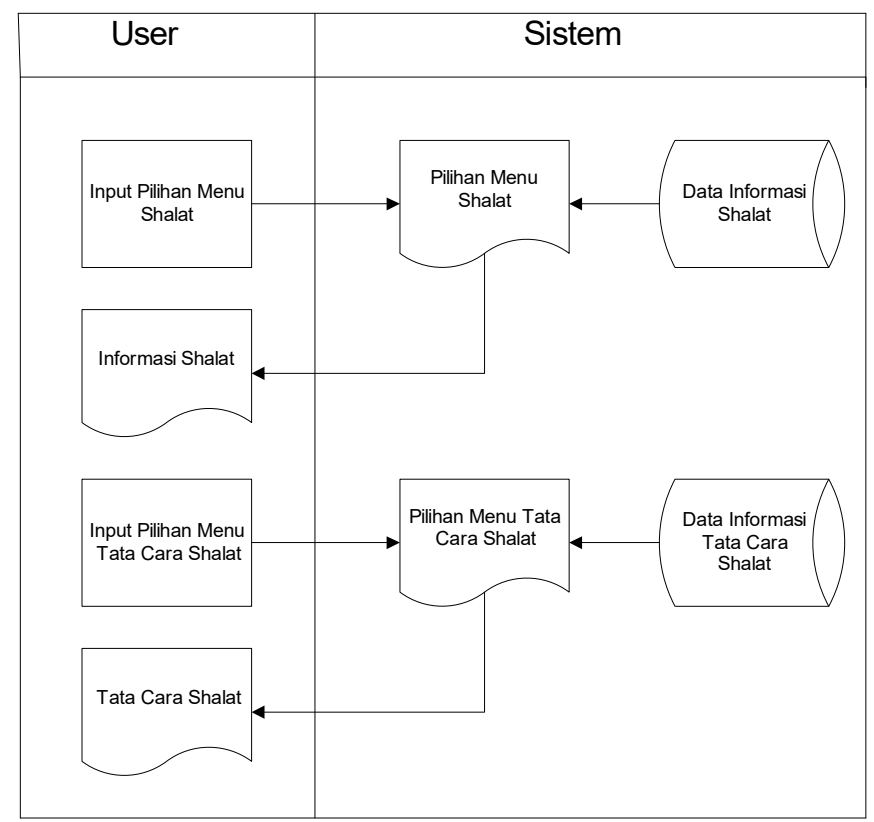

Figure. 3. New Business Process

\subsection{Use Case Diagram}

The above business process analysis results in the use case diagram that describes functional requirements for the application development as illustrated in Figure 4.

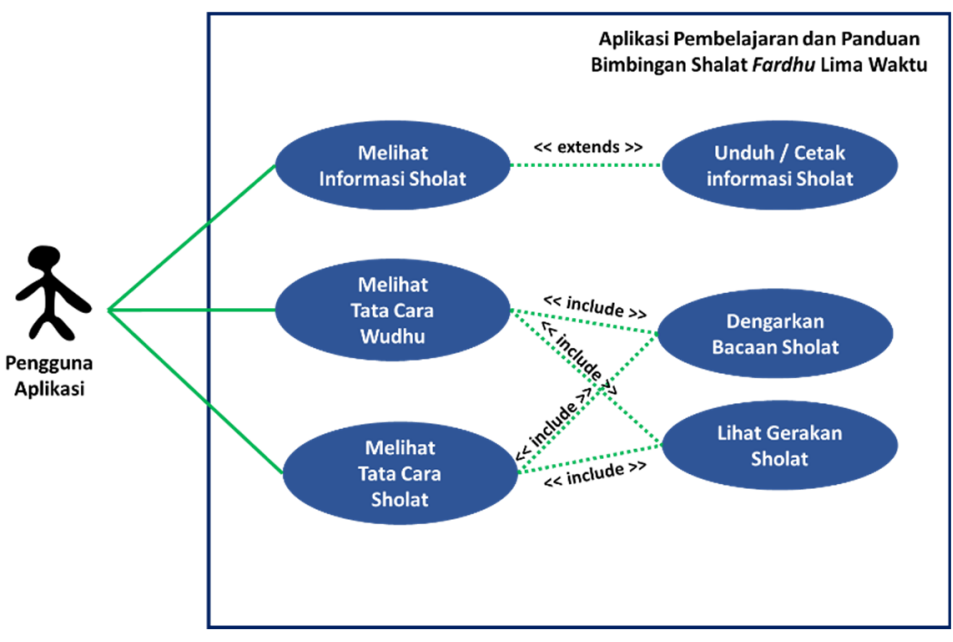

Figure. 4. Use Case Diagram 


\subsection{Application Site Map}

The application sitemap in Figure 5 is outlined based on the use case diagram in Figure 4.

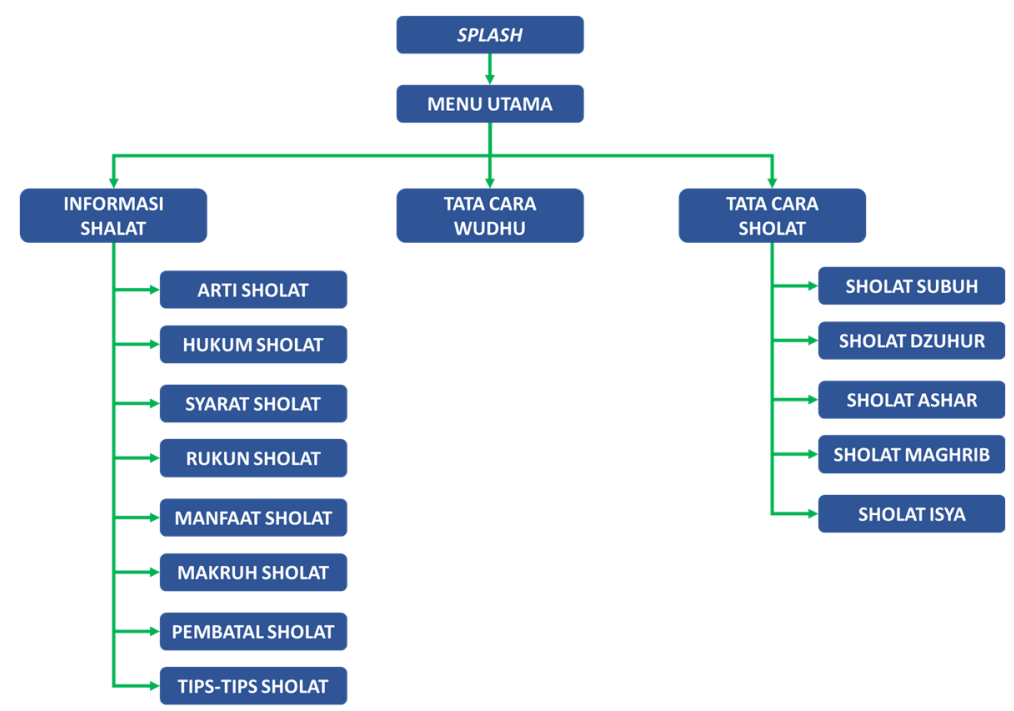

Figure. 5. Application Sitemap

\subsection{Interface Implementation}

What follows is the developed interactive multimedia interface.

1. Home menu

The home menu is the opening interface. It is designed as interesting as possible to the children as shown in Figure 6.

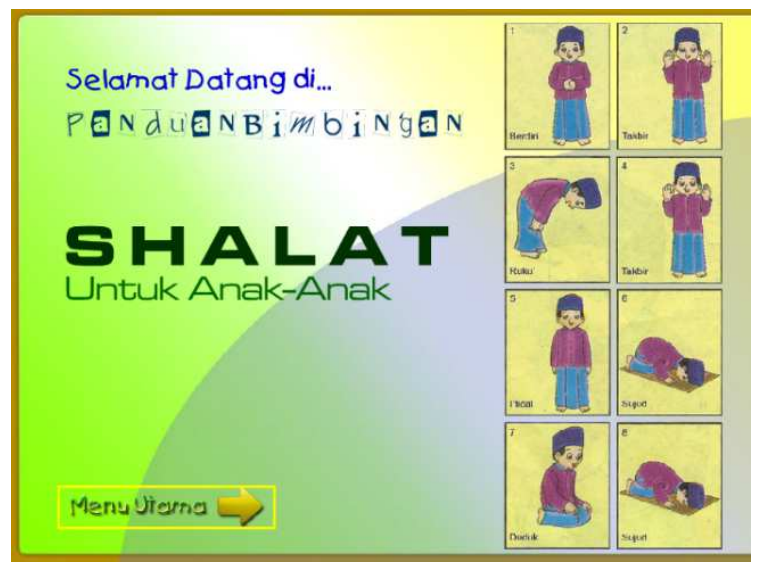

Figure. 6. Home Menu 


\section{Main Menu}

The main menu is the dashboard from which users can navigate to all other menus as shown in Figure 7.

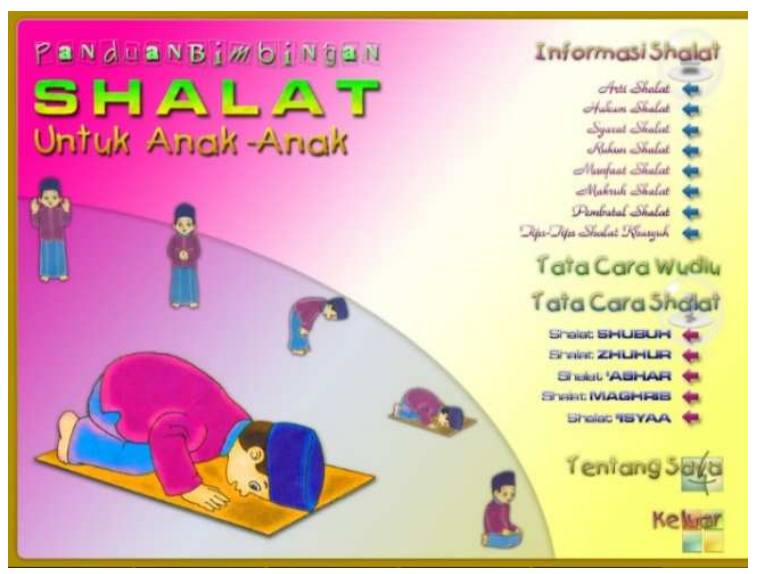

Figure. 7. Main Menu Interface

3. Information on salah

Information on salah refers to the basic concepts of salah children are expected to learn before they go to wudu and salah tutorial. These include definition of salah, hukm of salah, benefits of offering salah, what is forbidden during salah, and tips on how to perform salah with devotion. Figure 8 shows the interface for information on salah.

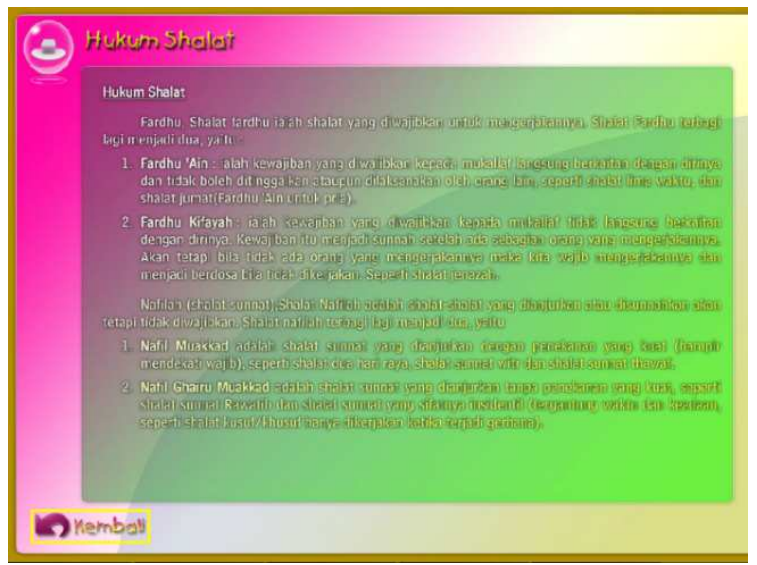

Figure. 8. Information on Salah 
4. Wudu tutorial interface

Wudu tutorial interface shows how to perform wudu in the given order along with its recitations. The interface is shown in Figure 9.

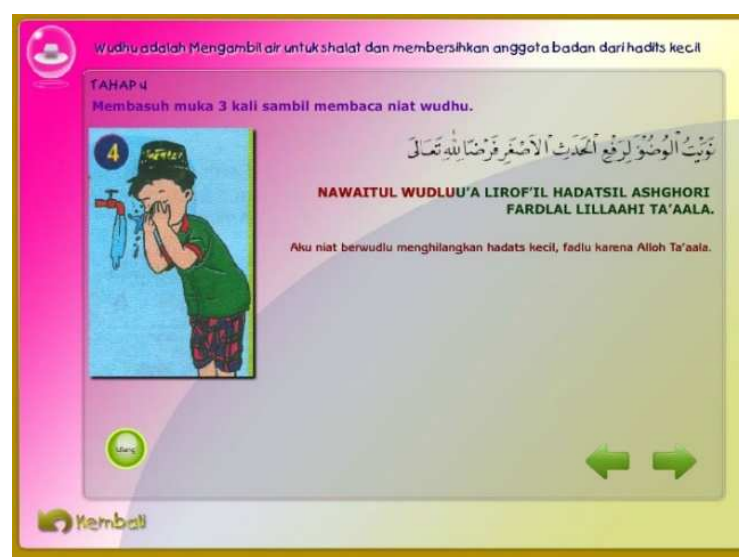

Figure. 9. Wudu Tutorial Interface

5. Salah tutorial interface

Salah tutorial interface consists of the main module of the salah lessons. This interface interactively displays salah simulation including recitations and movements. It has five submenus: Fajr salah, Zuhr salah, Asr salah, Maghrib salah, and Isha salah. The interface is shown in Figure 10.

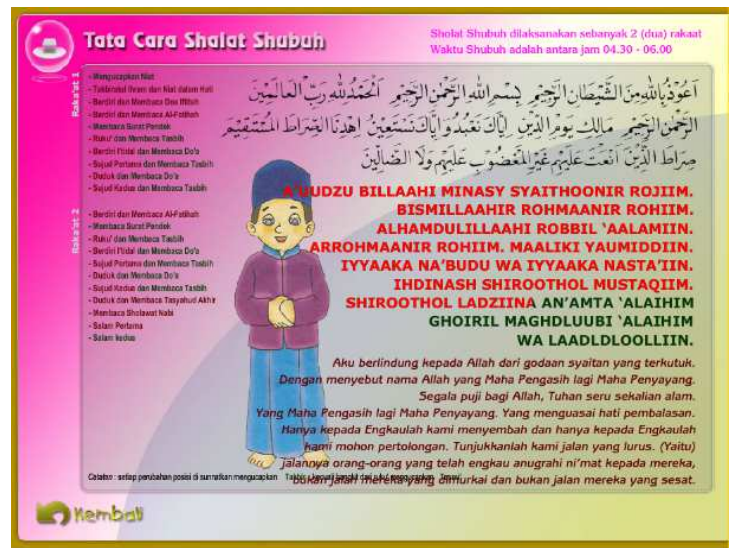



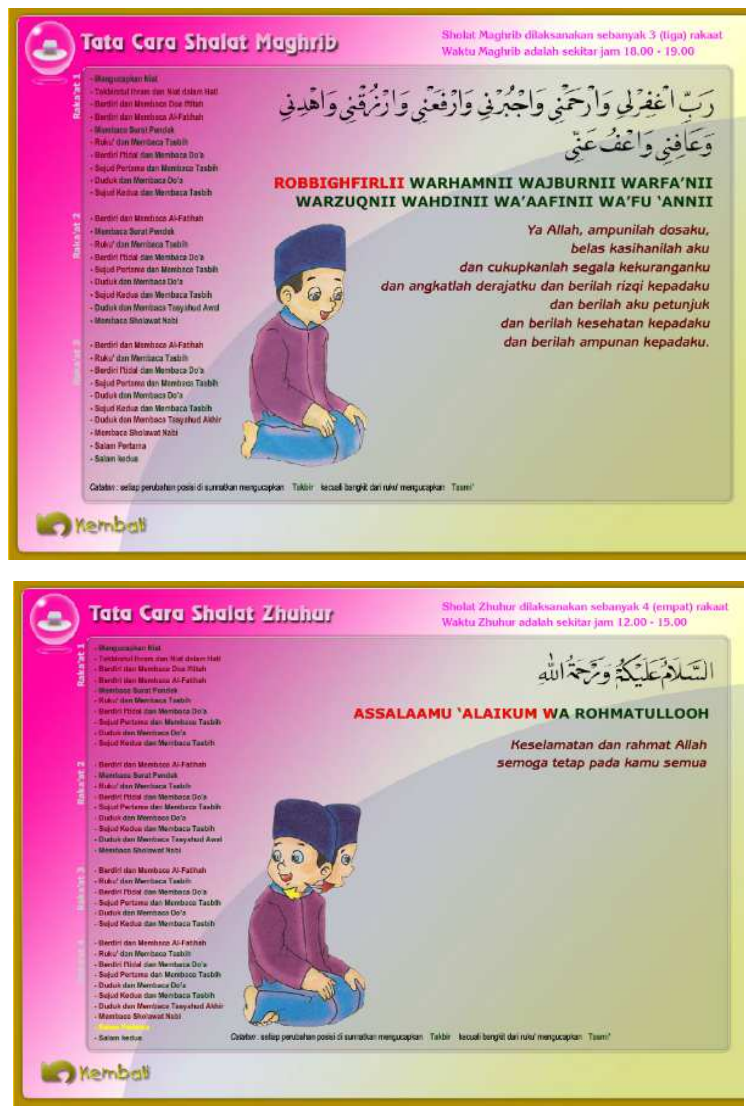

Figure. 10. Salah Tutorial Interface

\section{Conclusion}

The interactive multimedia for teaching five daily prayers must be designed as interesting as possible to elicit children's motivation to learn how to perform salah. The audiovisual tutorials in the form of animated texts and pictures can help children with adjust their salah recitations with the given movements. 


\section{References}

[1] E. Yulianto and G. A. F. Maulani, "CONCURRENCY PADA MATA KULIAH,” PETIK, vol. 4, no. September, pp. 149-161, 2018.

[2] G. Abdul Fatah Maulani, "Rancang Bangun Aplikasi Ensiklopedia Digital Tentang Tata Surya Berbasis Mobile Menggunakan J2ME," Petik, vol. 2, no. 2, pp. 11-16, 2016.

[3] Z. Zaitun and S. Habiba, "Implementasi Sholat Fardhu Sebagai Sarana Pembentuk Karakter Mahasiswa Universitas Maritim Raja Ali Haji Tanjungpinang," J. Pendidik. Agama Islam, vol. 11, no. 2, pp. 153-168, 2013.

[4] I. Fadzilatunnisa and D. Tresnawati, "Pengembangan aplikasi tata cara wudhu dan shalat untuk anak menggunakan sistem multimedia," J. Algoritm. Sekol. Tinggi Teknol. Garut, vol. 7, no. 1, pp. 1-7, 2015.

[5] M. Jasri and M. Faid, "Rancang Bangun Aplikasi Media Pembelajaran," Semin. Nas. Inov. Dan Apl. Teknol. Di Ind., p. 2, 2017.

[6] E. M. Hufnagel, "Information systems planning: Lessons from strategic planning," Inf. Manag., vol. 12, no. 5, pp. 263-270, 1987.

[7] Y. Bassil, "A Simulation Model for the Waterfall Software Development Life Cycle," vol. 2, no. 5, 2012.

[8] G. D. Everett and R. McLeod Jr., Software Testing Techniques in Software Development Life Cycle, vol. 5, no. 3. 2014.

[9] A. Dennis, B. H. Wixom, and R. M. ROth, SYSTEM ANALYSIS AND DESIGN Fifth Edition, Fifth. John Wiley \& Sons, Inc., 2012. 